\title{
Subterranean Microhabitat Dependent Intra Versus Extracellular Enzyme Secretion Capabilities of Deinococcus radiodurans
}

\author{
Jayant Biswas ${ }^{1}$, Arvind Neral ${ }^{2}$, \\ Yogita Rajput ${ }^{3 *}$
}
${ }^{1}$ National Cave Research and Protection Organization, Central Laboratory, Raipur - 492001, C.G., India.
${ }^{2}$ Department of Microbiology, Pt. J.N.M. Medical College, Raipur-492001, C.G., India.
${ }^{3}$ Viral Diagnostic Laboratory, Department of Microbiology, Pt. J.N.M. Medical College, Raipur, 492001, C.G., India.

Study Area: Kotumsar Cave, Jagdalpur, India

Coordinates: : $18^{\circ} 52^{\prime}$ o9o" N; 81 56’05” E

Key words: Deinococcus radiodurans, Alkaline protease,

Subterranean cave, Extremophilic bacteria, Kotumsar cave

\section{Abstract}

Deinococcus radiodurans is one of the most yet discovered extremophilic microbe, the isolation of which from the various habitats of Kotumsar cave is always a matter of enticement to discover its ecological economics. In the present work we studied the intra versus extracellular alkaline protease and glucose isomerase secretion capabilities of Deinococcus radiodurans; $\mathrm{KCB} 21, \mathrm{KCB}_{50}, \mathrm{KCB}_{93}$ isolated from three distinct subterranean niches of Kotumsar cave. The selected niches/zones were the entrance zone, transient zone and the deep inner zone from where the soil sediments were collected to isolate the bacterial strains. The results revealed high extracellular alkaline protease activity from the Deinococcus radiodurans strain which was isolated from the deeper zones of the cave, whereas no such phenomenon was revealed for glucose isomerase. The possible reason for the obtained results has been discussed. 


\section{Introduction}

Extremophilic species are capable to withstand the extreme ambient conditions and are always considered beneficial for a wide range of research and commercial purposes. Deinococcus radiodurans is a gram-positive, pigmented, non-spore forming, non-motile, spherical bacterium ranging from 1.5 to $3.5 \mathrm{im}$ in diameter and grows with a doubling time of $\sim 80$ min in a rich nutrient medium. It is one of the most extremophilic members from Deinococcaceae family which has extreme radiation resistant capacity due to which it is often referred as polyextremophile (Slade \& Radman, 2011). D. radiodurans has already been listed as the world's toughest bacterium in "The Guinness Book of World Records" (DeWeerdt, 2002). Nevertheless, till date very little attempt has been made to understand its ecological economics. In general it is difficult to isolate microbes like $D$. radiodurans from common soil, excreta, hay sample or domestic sewage but reports are available supporting its isolation from elephant trunks to granite outcrops in Antarctica are available (Daly \& Minton, 1996; Makarova et al., 2001).

Subterranean caves always represent an unusual ecosystem due to some of its uncommon geophysical characteristics viz., perpetual darkness, constant temperature, low energy input, relatively high humidity and $\mathrm{CO}_{2}$ concentration etc. Further, in such isolated subterranean environments gradual alterations in habitat are also apparent which is mainly due to alterations in internal factors viz., guano deposition, fungal colonies, biof ilm/foval soil etc. (Camassa, 1997). Thus the microbes which originate in such extreme environment could be safely referred as extremophilic species. In our earlier studies we have already reported the occurrence of $D$. radiodurans from various habitats (Biswas, 2010) of Kotumsar cave (Rajput et al., 2012). The occurrence of $D$. radiodurans in various habitats of the Kotumsar cave which is an almost energy starved ecosystem perhaps increases the possibility of its potential enzyme producing capabilities.

In the present study we have used three strains of Deinococcus radiodurans isolated earlier from the three distinct habitats of Kotumsar cave (Rajput et al., 2012) and tried to compare their intra and extracellular activities of two specific commercially important enzymes, alkaline protease and glucose isomerase.

\section{Materials and Methods:}

Study area: Kotumsar cave complex is composed of Kanger limestone of Indrawati group of rock of Upper Proterozoic. A permanent stream of River Kanger is always flowing at the foothill where the cave is situated. The main entrance of this cave is formed by a vertical fissure in the wall of a hill, which further leads inwards via a narrow, twisted tubular path, measuring about $15 \mathrm{~m}$ in length. The complete cave is nearly $150 \mathrm{~m}$ long at a stretch which having several lateral and downward passages leading to several irregular chambers (Biswas 1992a). The ambient external surface of this cave is covered by deciduous to mixed forest vegetation. The air and water temperatures of the cave remain relatively stable at an annual average of $28.25 \pm 1.23^{\circ} \mathrm{C}$ and $26.33 \pm 0.96^{\circ} \mathrm{C}$ respectively (range $=25.032 .7^{\circ} \mathrm{C}$ for air; $22.929 .3^{\circ} \mathrm{C}$ for water). The Kotumsar cave 
is subjected to tremendous flooding specially during rains which starts from June and continuous till the end of September in Kanger Valley National Park. The annual mean of percentage saturation for oxygen in this cave water were seen to $74.83 \pm 5.91 \%$ (Biswas, 1992b). The sediment samples for isolations of Deinococcus radiodurans were isolated from the entrance zone 'A' (nearer to the entrance of cave), transient zone 'B' (just few meters after the crossing of twisted vertical path) and the inner deep zone ' $\mathrm{C}$ ' (around $70 \mathrm{~m}$ deep inside the cave) (Fig.-1a, b).

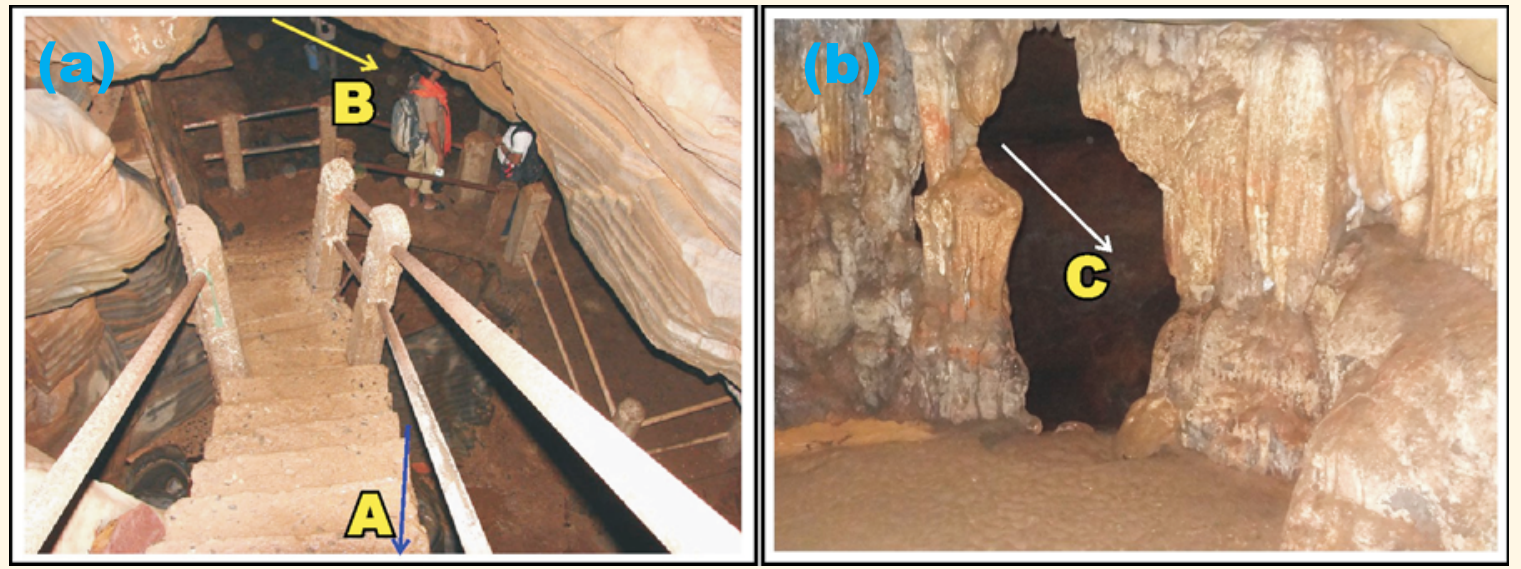

Figure- 1: Various zones of Kotumsar Cave from where the sediments were collected for isolation of Deinococcus radiodurans; a- entrance zone 'A' and transient zone 'B'; b- the deep inner zone 'C'

Screening of industrially important enzymes: as the first step, we prepared intracellular and extracellular crude enzyme extract from bacterial isolates followed by enzyme analyze process. All tested bacterial strains isolated from Kotumsar cave were screened for intra- and extra- cellular alkaline ptotease and glucose isomerase enzyme. Quantitative estimation were done by cystine/carbazole/sulphuric acid method (Dische \& Borenfreund, 1951).

a) Alkaline protease: The quantitative estimation of alkaline protease was done by Nakagawa, (1970) method.

The alkaline protease activity was determined by the enzymatic hydrolysis of haemoglobin at alkaline $\mathrm{pH}$. The liberated aromatic amino acid was measured in the trichloroacetic acid filtrate, which was allowed to react with Folin-Ciocalteau reagent, and the developed colour was measured at $750 \mathrm{~nm}$.

The aliquot of $1 \mathrm{ml}$ of haemoglobin solution was equilibrated at $37^{\circ} \mathrm{C}$ for $5 \mathrm{~min}$. The assay was initiated by adding $0.5 \mathrm{ml}$ crude enzyme and mixture was incubated at $37^{\circ} \mathrm{C}$ for $10 \mathrm{~min}$. At the end of incubation period the reaction was terminated by addition of $2 \mathrm{ml}$ of $5 \%$ trichloroacetic acid (TCA). The suspension was allowed to stand for $5 \mathrm{~min}$. and centrifuged at $5000 \mathrm{rpm}$ for $20 \mathrm{~min}$. In the control set, TCA was added before the enzyme addition, to stop the enzymeactivity.

One $\mathrm{ml}$ supernatant was allowed to react with $5 \mathrm{ml}$ of alkaline solution for $10 \mathrm{~min}$ followed 
by addition of $0.5 \mathrm{ml}$ Folin Ciocalteau reagent and the colour developed after $15 \mathrm{~min}$. was measured $750 \mathrm{~nm}$ in UV- visible spectrophotometer (Shimadzu). The specific activity was expressed as ìg tyrosine formed per mg protein per min.

b) Glucose isomerase: Quantitative estimation of xylose (glucose) isomerase was done by cystine/carbazole/sulphuric acid method (Dische \& Borenfreund, 1951)

The reaction mixture contained $1 \mathrm{ml}$ buffer solution, $0.5 \mathrm{ml} \mathrm{D}$-glucose and $0.5 \mathrm{ml}$ crude enzyme (extra- and intra-cellular). After incubation of the reaction mixture at $37^{\circ} \mathrm{C}$ for $15 \mathrm{~min}$., $1 \mathrm{ml}$ of $0.5 \mathrm{M}$ perchloric acid was added to stop the enzyme reaction. The product was determined by the cysteine/ carbazole / sulphuric acid method. In this procedure, $1 \mathrm{ml}$ of supernatant (fructose formed from enzymatic action), $0.2 \mathrm{ml}$ cysteine hydrochloride, $6 \mathrm{ml}$ $\mathrm{H}_{2} \mathrm{SO}_{4}$ and $0.2 \mathrm{ml}$ carbazole solution were added sequentially, shaken and allowed to stand for 5 min. at room temp. Fructose gave purple colour and extinction was read against blank at 560 $\mathrm{nm}$ in UV- visible spectrophotometer (Shimadzu). The specif ic activity was expressed as ìg fructose formed per mg protein per min.

Statistical analysis: Two-way ANOVA was employed to verify the microhabitat effects on intra as well as extracellular enzyme; alkaline protease and glucose isomerase activities separately. Further the ANOVA results was followed by Duncan's Multiple Range Test (Duncan, 1955) to verify the statistically significance differences among every groups separately.

\section{Results and Discussion:}

(Results are summarized in Table 1a,b and Figure 2a,b)

\begin{tabular}{|llllll|lllllll|}
\hline Table-1a: & $\begin{array}{l}\text { ANOVA } \\
\text { Protease }\end{array}$ & Summary & for & Alkaline & Table-1b: & $\begin{array}{c}\text { ANOVA } \\
\text { Isomerase }\end{array}$ \\
\hline Source & SS & df & MS & F & P & Source & SS & df & MS & F & P \\
Habitats & 2157.46 & 2 & 1078.73 & 311.25 & $<.0001$ & Habitats & 231.29 & 2 & 115.65 & 1186.1 & $<.0001$ \\
I Vs E* & 181.9 & 1 & 181.9 & 52.48 & $<.0001$ & I Vs E* & 278.76 & 1 & 278.76 & 2859.1 & $<.0001$ \\
Habitat X & 1071.04 & 2 & 535.52 & 154.51 & $<.0001$ & Habitat X & 237.38 & 2 & 118.69 & 1217.33 & $<.0001$ \\
I Vs E* & & & & & & I Vs E* & & & & & \\
Error & 41.59 & 12 & 3.47 & & & Error & 1.17 & 12 & 0.1 & & & \\
Total & 3451.99 & 17 & & & & Total & 748.6 & 17 & & & \\
\hline
\end{tabular}

*Intra Vs Extracellular

(SS- sum of squares; df- degree of freedom, MS- mean square)

Inside the Kotumsar cave, the intra as well as extracellular enzyme activities of Deinococcus radiodurans for both alkaline protease and glucose isomerase were seen to be highly regulated with accordance to its ambient microhabitat conditions. Irrespective to both the studied enzymes, ANOVA results revealed very high statistically significant differences among all the employed parameters viz., habitats, Intra Vs Extracellular activities and also their 
interactions. Further, the results from Duncan's multiple range test revealed high activity of Intracellular alkaline protease in strains; $\mathrm{KCB}_{21}$ and $\mathrm{KCB} 93$ i.e., the D.radiodurans strains isolated from the entrance ' $\mathrm{A}$ ' and inner deep ' $\mathrm{C}$ ' zones whereas the strain $\mathrm{KCB}_{5}$ o isolated from the transient zone 'B' revealed very low activity of alkaline protease (Fig.-2a). Nevertheless, the extracellular alkaline protease production was seen to be increased with respect to the consistency of the cave environment i.e., the lowest alkaline protease activity was revealed from the strain isolated from the entrance zone ' $\mathrm{A}$ ' than in the transient ' $\mathrm{B}$ ' and highest was evidenced from the strain isolated from the inner deep zone ' $\mathrm{C}$ ' (guano mix soil). Interestingly, extracellular alkaline protease activity of the isolated strain $\mathrm{KCB} 93$ isolated from the inner deep guano soil was also seen to be compatible to its intracellular counterpart (Fig.2a).

Further, the intracellular glucose isomerase activity was found to be very low in the strain $\mathrm{KCB}_{50}$ isolated from the transient zone 'B', whereas its extracellular glucose isomerase activity was found to be compatible with the glucose isomerase activity revealed from strain $\mathrm{KCB} 21$, isolated from the entrance zone 'A'. However, both the extracellular and intracellular glucose isomerase activities revealed by the strain $\mathrm{KCB} 93$ isolated from the inner deep zone ' $\mathrm{C}$ ' were found to be comparatively low (Fig.-2b).

Enzymes have been used since the beginning of the human civilization. Earlier it was restricted only to some domestic food processing phenomena, but later on i.e., from the twentieth century the concept of using enzyme as a detergent got momentum and enzyme production in bulk quantities started. When selecting a right strain to produce a desired enzyme, several aspects have to be considered which include high production in limited timeframe, required less purification process and optimum ambient conditions etc. The extracellular secretion of any enzyme is always preferable than its intracellular counterpart as, the recovery and purification process against extracellular enzyme productions is always much easier than its intracellular ones. It is mainly to avoid the various processes of purif ications of the same from numerous types of cell proteins and other components associated with it (Leisola et al., 2002). Hence, intensive screening programs are required to test a large number of strains for identifying the best producers that can yield high production along with novel properties.

Bacteria secrete proteases to digest (hydrolyse) the peptide bonds. Alkaline proteases are a very important group of enzymes due to its notable physiological and high commercial values. Primarily it is an essential requirement as detergent additives; in addition, it is also used in 
leather processing, silver recovery, medical purposes, food processing, feeds, chemical industries and waste treatments as well. As it has already been discussed, being one of the toughest extremophilic bacteria, D.radiodurans is hard to isolate from common resources, thus the isolation of the same from various habitats of Kotumsar cave always enticed us to compare the enzyme production abilities with respect to their various habitats of occurrences. In the present study we found that the alkaline protease activity was high in the strain which was isolated from the guano mixed sediment of inner most zones "C" of the Kotumsar cave. Indeed, in extremophiles structural adaptations at the molecular level have already been proposed to cope up with the ambient exacting conditions. Earlier Rajput et al., (2012) stated that $D$. radiodurans strain KCB21, isolated from the sediment of entrance zone revealed limited protein bands, whereas the remaining strains of the same species isolated from deeper zones of the cave exhibited different specific protein bands of high molecular weights. In the present study, with regards to the apparent high potency of the strain $\mathrm{KBC} 93$ for extracellular alkaline protease activity, we can predict two possibilities for the same; a) the energy starved and almost constant ecological conditions of the inner deep zone of the cave increases the production of protease perhaps to hydrolyze more peptide bonds to survive b) various types of animal body parts remain as undigested materials in guano which leads to an increase in the protease activity in D.radiodurans. Due to energy starved conditions, various morphological, behavioural and physiological alterations in various bigger fauna abiding inside the Kotumsar cave havealready been reported (Biswas, 1991; 2010; Biswas \& Dey, 2014).

The most important role of Glucose isomerase is its interconversion of pentose and glucuronate as well as the metabolism of fructose and mannose. As an enzyme it has the largest market in the food industry because of its application in the production of high-fructose corn syrup (HFCS). In the present study, we found that the extracellular activity of glucose isomerase remains almost same in the strain isolated from the entrance " $\mathrm{A}$ " and the transient "B" zone (KCB21 \& KCB50). Surprisingly the intracellular glucose isomerase activity of the strain $\mathrm{KCB}_{50}$ isolated from the transient "C" zone was revealed very low. Similarly, both the intra and extracellular glucose isomerase activity for the strain KBC93 isolated from the innermost " $C$ " zone of the cave were also revealed statistically too low. This clearly shows that strains isolated from deeper habitats have a direct relation to decreasing levels ofthe glucose isomerase activity. However, when compared to the isolate of transient zone KCB50, less elevation in intracellular glucose isomerase activity was revealed in KCB93. This may be due to its growth in guano mixed soil that may contain undigested food materials of cave roosting bats.

\section{Conclusion:}

The D.radiodurans strain KBC93, isolated from the deep inner zone of the Kotumsar cave reveals high potency for extracellular alkaline protease which directly opens a window for searching of useful enzymes from more and more microbes existing in such extreme ecological niche. 


\section{Acknowledgements:}

Corresponding author (YR) is thankful to the Head (ex), School of Life Sciences, Pt. Ravishankar Shukla University for providing her laboratory facilities to carry over a part of this study in its initial stage. Authors are also thankful to the members of the National Cave Research and Protection Organization for helping them to bringing proper sediment samples from the Kotumsar Cave.

\section{References:}

Biswas, J (1991): Metabolic efficiency and regulation of body weight: a comparison between life in hypogean and epigean ecosystems. Int. J. Speleol., 20 (1), 15-22.

Biswas, J (1992a): Kotumsar cave ecosystem: An interaction between geophysical, chemical, and biological characteristics. NSS BULL. 54(1): 7-10

Biswas, J (1992b): Influence of epigean environmental stress on a subterranean cave ecosystem: Kotumsar. Biome. $5(1): 39-43$

Biswas, J. (2010): Kotumsar Cave biodiversity: a review of cavernicoles and their troglobiotic traits. Biodivers. Conserv., 19(1):275-289

Biswas, J. \& Dey, M. (2014): Troglomorphy: habitat dependent morphological divergence in two forms of a fish from Kotumsar Cave of Kanger Valley National Park, India. International Colloquium on Endocrinology and Physiology. (DOI: 10.13140/2.1.2719.8244)

Camassa, M. (1997): Biological observations in an artif icial cave of Ginosa (Southern Italy): Role of the foval in cave ecosystems. Thalassia Salentina, 23:189-191.

Duncan, D.B. (1955): Multiple range and multiple f tests. Biometrics, 11: 1-42.

Daly, M.J. \& Minton, K.W. (1995): Resistance to radiation. Science, 270 (5240): 1318

DeWeerdt, S.E. (2002): The World's Toughest Bacterium: Deinococcus radiodurans may be a tool for cleaning up toxic waste and more. Genome News Network.

Availableat:www.genomenewsnetwork.org/articles/o7_02/deinococcus.shtml

Dische, Z. \& Borenfreund, E. (1951): A new spectrophotometric method for the detection and determination of keto sugars and trioses.JBiol Chem., 192: 583-587

Leisola, M., Jokela, J., Pastinen, O., Turunen, O. \& Schoemaker, H. (2002): Industrial use of enzymes in Encyclopedia of Life Support Systems (EOLSS), O. O. P. Hänninen and M. Atalay, Eds., pp. 125, EOLSS, Oxford, UK, 2002

Makarova, K.S., Aravind, L., Wolf, Y.I., Tatusov, R.L., Minton, K.W., Koonin, E.V. \& Daly, M.J. (2001): Genome of the extremely radiation-resistant bacterium Deinococcus radiodurans viewed from the perspective of comparative genomics. Microbiol Mol Biol Rev., 65(1):44-79

Nakagawa, Y. (1970): Alkaline proteases from aspergillus. Method. Enzymol. 19:581-591

Rajput, Y., Rai, V. \& Biswas, J. (2012): Screening of Bacterial Isolates from Various Microhabitat Sediments of Kotumsar Cave: A Cogitation on Their Respective Benef its and Expected Threats for Complete Biosphere and Tourists. Research J. Environ. Toxicol., 6 (1):13-24

Slade, D \& Radman, M (2011) : Oxidative stress resistence in Deinocossus radiodurans. Microbiol. Mol. Biol. Rev., 75(1):133-139 